\title{
Practice and Reflection on Bilingual Teaching on Course of Principles of Economics
}

\author{
Haiying $\mathrm{Ma}^{*}$ \\ School of Economics, Northwest University for Nationalities Lanzhou (730124), P.R.China \\ Ixmahaiying8888@163.com
}

Keywords: Bilingual teaching; Principles of economics; Northwest University for nationalities

\begin{abstract}
The construction of bilingual teaching course is one of the important contents of the undergraduate education quality project of Northwest University for Nationalities. Principles of Economics is an important basic course of economics. This paper first elaborates the concept of bilingual teaching, analyzes the significance of bilingual teaching of Principles of Economics, and explores the bilingual teaching practice of the course in the School of Economics, Northwest University for Nationalities, aiming at solveing the problems of bilingual teaching in thenic colleges and universities in China.
\end{abstract}

\section{Introduction}

With China's accession to the WTO, more and more domestic enterprises to participate in international competition, with the international common language thinking, work, the ability to communicate more and more attention. National educational institutions and institutions have been thinking about how to adapt to this trend and to promote learning at all levels. Bilingual teaching is an attempt in this context. The definition of bilingual teaching is defined as the use of a second or foreign language in school for the teaching of content subject, which is defined by the Langman Dictionary of Applied Linguistics published by the famous Longman Press in the UK. Bilingual and bilingual teaching are defined as: the student's foreign language or a second language, through teaching and the environment and several stages of training, it can replace to the mother tongue level of expression. Bilingual teaching in China mainly refers to the teaching of Chinese and international English. Based on the practice of bilingual teaching, Northwest University for Nationalities has been active in the construction of bilingual teaching courses, and has made great achievements. Combining with the practice of bilingual teaching of Economics Principles in Northwest University for Nationalities, this paper explores bilingual teaching in colleges and universities.

\section{The Importance of Bilingual Teaching in Economics}

Bilingual Teaching is an Important Part of the Professional Curriculum System. Bilingual teaching of The Principles of Economics is major courses, Principles of Economics in bilingual teaching is essentially a professional course, Overall, its primary task is to focus on the professional training objectives to play the basic functions of specialized courses.

Enhance the Timeliness of Theory, Training to Adapt to International Talent. With the China's accession to the WTO, the economy is gradually with international practice, as a professional basic course of the Principles of Economics using bilingual teaching, you can select advanced to reflect the forefront of scientific development of the original textbooks and related foreign language teaching, Economic theory development frontier, enhance timeliness.

To Promote the Practicality of Curriculum Teaching. In bilingual teaching, the general use of foreign original textbooks is characterized by strong practicality, and this is precisely the Chinese textbooks for many years the weak link. A large number of foreign textbooks with a variety of cases, through the analysis of cases, students can analyze and solve problems, so that students can learn something applied to the actual work. 
Improve the Students 'Foreign Language Proficiency and Teachers' Research Level. In the course of bilingual teaching, students can expand their English vocabulary and acquire more grammar knowledge by reading the dictionary and related grammar books in order to read the original Principles of Economics. At the same time, through bilingual teaching, students' English practical ability and comprehensive application ability of listening, speaking, reading and writing have been greatly improved.

\section{The Practice of Bilingual Teaching in Economics}

Teaching Arrangement and Adjustment of Teaching Syllabus. The Arrangement of Bilingual Teaching in Principles of Economics. According to the teaching plan, the Northwest University for Nationalities will be the economics of "economics" bilingual teaching time in the second year of college. Through more than a year of college English learning, students also have a good foundation for English, in order to successfully pass the CET-4 and 6 test preparation, many students are trying to learn English, then bilingual teaching for students is relatively difficult Smaller, to avoid the students at the beginning to produce fear of hard feelings. In order to meet the needs of bilingual teaching, we adjusted the syllabus of Principles of Economics, including the teaching materials, teaching objectives, teaching methods and teaching methods, as well as students' performance assessment. Selection of Teaching Materials and Development of Vocabulary. Combined with the actual situation of students choose bilingual materials. "Mankun Principles of Economics" Although the language fluency, readability, but the content is cumbersome, logic is relatively poor. After repeated screening, the choice of the Chinese People's University Publishing House published the Principles of Economics bilingual materials, the textbooks by the US economist Professor Carl E. Case and Ray. C. Fair co-authored by Professor Wu Hanhong. The original textbooks are not suitable for teaching and do not meet the content of China's national conditions, not only to maintain the characteristics of English original textbooks, but also close to China's reality, to facilitate teaching and students to understand and master. In addition, in order to make it easier for students to understand the contents of bilingual teaching materials and to reduce the difficulty of learning, teachers also recommended a representative book in Chinese to supplement the Principles of Economics. In the formulation of vocabulary, according to the provisions of bilingual teaching of the Northwest University for Nationalities. The vocabulary of the economic principles of the important vocabulary chapters are written, so that students of the Principles of Economics in the important vocabulary at a glance, learning easier to grasp the key points, received good results.

Bilingual Teaching Method. Taking into account the overall level of English students in the "Principles of Economics" bilingual teaching is mainly used to maintain the maintenance bilingual education) and Participation bilingual education bilingual teaching method. In the maintenance of bilingual teaching, teachers balance the use of two kinds of teaching language, the bilingual writing on the blackboard and annotation, the complexity of the theoretical content of the most simple language to express, so that students can successfully understand and master the teaching content and knowledge, but Some difficult content to explain in Chinese. The so-called participation method is to provide some of the necessary conditions for the analysis of the problem, through questioning, guidance and inspiration, so that students actively participate in classroom teaching with economic thinking.

Teaching methods. In the Principles of Economics, bilingual teaching process use of multimedia teaching. Modern teaching facilities are not only an auxiliary means to implement bilingual teaching, but also an extension of bilingual teaching. In the course of bilingual teaching of Principles of Economics, multimedia courseware and courseware are used to make the teaching easier.

After-school assignment. In order to consolidate the knowledge learned in the classroom, teachers require students to use extra-curricular time to review the contents of the classroom, grasp the key points of knowledge and professional expression, read the relevant economics materials in English. Due to the limited time of lectures, many students have not fully grasped the economic theories and formulas.

Performance assessment. According to the characteristics of the curriculum, the teachers use the assessment methods such as spoken and written English question and answer questions, curriculum 
papers, and final examinations in the process of bilingual teaching. The number of speeches, the quality and the level of the students' speeches in class are all included in the final grades in order to encourage the active participation of students and improve their language expression. level of thinking and knowledge to master the degree. Curriculum papers can be completed in Chinese, requiring students to observe the daily life of some economic phenomena explained. The final test questions from the test paper library in English, asked to answer in English assessing the students professional English reading ability. The composition of the students' graduation percentage is: $30 \%$ of spoken and spoken English question and answer, $20 \%$ of course papers, $50 \%$ of final examinations.

\section{Problems in Bilingual Teaching Practice}

At present, many colleges and universities in China regard bilingual teaching as an important teaching quality project to build. On the basis of bilingual practice of Principles of Economics, it is of great significance to study the problems existing in the practice of bilingual teaching in Chinese universities.

On the Establishment and Definition of Bilingual Teaching Courses in Colleges and Universities. At present, most of the colleges and universities have been more or less bilingual teaching of some professional courses, but the curriculum is generally lack of unified planning and demonstration, especially in the bilingual teaching start-up phase, due to teacher force constraints, Because of the phenomenon of teaching is very common, what teachers on what class. In addition, the bilingual teaching of colleges and universities is still not a unified definition. Some schools directly incorporate bilingual teaching into the category of foreign language teaching. The aim is to learn foreign language and improve students' foreign language level.

Teaching Effectiveness. Part of the survey results show that: Although college students want to carry out bilingual teaching, but bilingual teaching is not very good. The main reasons affecting bilingual teaching are as follows: First, the teacher's spoken English level. Teachers' oral English level is the key to the success or failure of bilingual teaching. Bilingual teaching requires teachers to have a deep English language skills, although many teachers have a master's and doctoral degrees, have a higher reading, writing, translation ability, but the ability to listen and speak need to be further improved. Second, the ability of students to accept questions. Teaching practice shows that even with the four levels of English undergraduate students, reading the efficiency of the original textbooks of economics is far from the level of its Chinese reading, the performance of the slow reading, the understanding is not in place and so on. Third, some curriculum theory itself is more difficult. Fourth, the teaching art of teachers. Some bilingual teachers still adopt the traditional teaching methods of full house, which makes the classroom atmosphere dull and the contents of teaching boring, which seriously affect the enthusiasm of students to learn bilingual, which leads to the bilingual teaching effect is not good.

On the Teaching Plan in Colleges and Universities. At present, China's colleges and universities in the implementation of the credit system teaching plan, which requires training objectives and teaching plans in accordance with the various courses and teaching links to determine the amount of each course hours and credits, but some schools of the credit system teaching plan failed to reform Thus restricting the development of bilingual teaching. For example, Principles of Economics in the management of professional colleges and universities is a required course, usually 2.5 credits, the corresponding number of hours of 40 hours. However, the "Principles of Economics" as a bilingual curriculum to be opened, the hours and credits have not done the appropriate adjustments, thus affecting the development of bilingual teaching.

Bilingual Teaching and Students' Publics. Students who study bilingual courses often spend more time and effort than mother-tongue courses. Because of the poor foundation of students in general colleges and universities, many students begin to prepare for postgraduate entrance examination after entering the second grade. At present, the domestic graduate entrance examination, including the domestic key university graduate entrance examination, specialized courses designated reference materials are basically the Chinese version of the exams are in Chinese respondents, which produced a bilingual teaching and examination section of the phenomenon. Students spend a lot of time and effort to learn the original textbooks, but the Graduate Entrance Examination has to use the Chinese answer, 
forcing students to study the original textbooks, but also self-study institutions designated Chinese textbooks. In addition, bilingual courses in colleges and universities are not set up specifically for Kaoyan, and many bilingual courses is not a graduate entrance examination subjects, which will also affect the students of bilingual courses to learn initiative.

\section{Conclusions and Some Suggestions on Bilingual Teaching}

Bilingual Teaching is Scientifically Defined, and the Bilingual Education Curriculum Access System is Implemented. Different bilingual education in different colleges and universities may be defined differently, but should grasp the following points: (1) bilingual teaching must use foreign original textbooks, the use of adapted textbooks or translated textbooks can not be regarded as complete bilingual teaching or can not be counted as bilingual teaching. (2) Bilingual teaching of classroom teaching, classroom discussions, homework and performance assessment and other major teaching links must be completed in foreign languages or most of the completion in foreign languages. (3) Teaching content of bilingual teaching must be a student has not previously learned new professional knowledge. If the students have learned in the mother tongue of professional knowledge, its purpose can only learn a foreign language; can only be included in the scope of professional foreign language classes. Northwest University for Nationalities has introduced the relevant bilingual teaching documents, the bilingual teaching curriculum acceptance inspection system. The college organizes peer-to-peer courses to classify and classify the students, review relevant materials.

To Strengthen Bilingual Teacher Training and Construction, and Actively Carry out Bilingual Teaching and Research Activities. First, strengthen the bilingual teachers' English proficiency training. The school organizes an intensive English training program on weekends and holidays, focusing on bilingual teachers' oral English, listening and grammar knowledge. After the start of bilingual teaching quality project, the Northwest University for Nationalities has repeatedly invited senior teachers of English major to strengthen the bilingual teaching team of the college to enhance the comprehensive English level of the teacher through teaching and oral practice, and achieved good results. Second, the bilingual teachers teaching art training. Bilingual teaching in colleges and universities in order to achieve good results, the art of teaching is essential. Colleges and universities can organize the teaching of rich experience, high level of teaching teachers of the school's bilingual teachers teaching art instruction, demonstration, in order to continuously improve the effect of bilingual teaching and stimulate students' enthusiasm for learning. Third, qualified schools can be divided into batches bilingual teachers are sent to well-known universities both at home and abroad for training so as to continuously improve bilingual teachers' teaching level.

Reasonable Adjustment of Teaching Plans. University teaching plan should be adjusted according to the changes in the situation, colleges and universities to carry out bilingual teaching quality engineering construction, teaching plan should also make corresponding adjustments. First of all, the bilingual teaching credits and hours of the corresponding adjustments. Since there is no language environment for English learning in China, it is very difficult to carry out bilingual teaching. Bilingual teaching will take more time to teach the same professional knowledge. Thus bilingual courses should be considered as appropriate to improve the credit to improve student motivation, increase the class so that students are more receptive to the appropriate expertise to improve teaching effectiveness. Secondly, in the bilingual curriculum should be fully considered when the links between the courses and differences in the bilingual class and other courses do a good job between the coordination, analysis and research bilingual classes and other specialized courses in the order of time to determine the bilingual teaching Set up time.

Establishment of Bilingual Teaching Incentive Mechanism. With the deepening of bilingual teaching practice, colleges and universities have established the corresponding incentive mechanism to promote the smooth development of bilingual teaching. Bilingual teaching is the key to the success of the formation of benign interaction between teachers and students; therefore, the establishment of bilingual teaching incentive mechanism includes both incentives for teachers, including incentives for students. In terms of incentives to teachers, colleges and universities should dilute the impact of student ratings on 
teacher evaluation, the introduction of relevant policy documents to stimulate the enthusiasm of bilingual teachers.

Handle the contradiction between bilingual teaching and students. In order to make bilingual education develop benignly, it is necessary to gradually solve the contradiction between bilingual teaching and postgraduate entrance examination. From the teaching point of view, in bilingual teaching, according to the needs of the original textbook content to make the necessary trade-offs. Teachers in the process of teaching bilingual classes, combined with the teaching content of each chapter, and more involved in some of the college entrance examination over the years the professional examination questions. From the perspective of university entrance examination reform, we should gradually straighten out the relationship between the two.

\section{References}

[1] Zheng Liancheng, Bilingual teaching of economics. Harbin Financial College, 1(2008) 51-52.

[2] Li Tao, Bilingual teaching from the implementation of the results of the questionnaire" to get the inspiration, Journal of Qiqihar Medical College, 20(2007) 96-101.

[3] Song Juan, Tian Hua, Bilingual teaching of pharmacology questionnaire analysis, 2008.

[4] Shi Yutian, Economic Discipline Bilingual Teaching Course System Analysis, Taxation and the economy, 6(2004)73-74.

[5] Hu Huimin, Fan Dandong. Some Suggestions on Bilingual Teaching in Economics in Colleges and Universities.2012.

[6] He Pinghua, Microeconomics bilingual teaching practice and exploration. Journal of Huazhong Agricultural University (Social Science Edition), 5(2005) 177-180.

[7] Shi Yutian. Bibliometric problems in economics courses and countermeasures.

[8] Dong Zhanmei, Bilingual teaching reform of international trade courses in vocational colleges, Vocational Education Research, 8(2005)89-95.

[9] Cheng Dajun. International Trade Practice course bilingual teaching strategy. Journal of Zhejiang Business Technology College, 4(2005)66-74.

[10] Xiong Wei. International Trade Practice English. Wuhan: Wuhan University Press, 2001. 